\title{
Polymorphic Microsatellite Loci and Low-invasive DNA Sampling in Macaca cyclopis
}

\author{
Jui-Hua CHu \\ Academia Sinica and National Taiwan University \\ HAI-YIN Wu \\ Academia Sinica \\ YI-JU YANG \\ Tsu Chi College of Medicine and Humanities \\ OSAMU TAKENAKA \\ Kyoto University \\ and YAO-SUNG LiN \\ National Taiwan University
}

\begin{abstract}
Polymorphic genetic markers and methods for DNA sampling in the field are the basic requirements for studies on population and conservation genetics of wild Macaca cyclopis. In this paper we screened microsatellites for their polymorphism and accessed the validity in paternity identification and gene typing of DNA samples from various sources. Among the 36 primer sets tested, 21 are polymorphic with an average observed heterozygosity 0.56 . All the eight loci examined for a parent-offspring triad followed Medelian inheritance. Application of the two most polymorphic loci in paternity identification of a captive group showed that the top-ranking male sired all the juveniles. DNA samples from wound and menstrual bleeding, or from ejaculates and hairs produced concordant microsatellite banding patterns for specific individuals. The success in DNA extraction from samples collected low-invasively and the polymorphic loci screened in this study can be applied in future studies on population and conservation genetics of natural primate populations.
\end{abstract}

Key Words: Microsatellite; Polymorphism; Low-invasive sampling; Paternity test; Macaca cyclopis.

\section{INTRODUCTION}

Macaca cyclopis is an endemic primate species in Taiwan. It is distributed in a variety of forested habitats from sea level up to $3,400 \mathrm{~m}$ (MAsul et al., 1986). Fluctuations in population size and distributional range the species experienced in the past decades make it a good subject for studies on conservation genetics. $M$. cyclopis was once heavily trapped and hunted as food, medicine, and pets. Since the implementation of the wildlife conservation law in 1989, the population size of $M$. cyclops over the whole island increased. On the other hand, during the period of economic miracle, extensive forest destruction and human activities produced many isolated forest patches, some of which were inhabited by monkeys. Recovering from small monkey groups inhabiting isolated habitats, some local populations might have lost or would lose genetic diversity due to bottleneck and inbreeding effects. It offers an opportunity to examine the interactive effects of habitat fragmentation, isolation, and bottleneck on the genetic structuring of a species. Sreening genetic markers and developing working field techniques should be the very first steps for such study. Fortunately, these requirements are met by the advent of PCR and the application of microsatellites as genetic markers. 
Microsatellites are increasingly used in molecular ecology and genetic analysis of wildlife populations. This Mendelian marker is useful in individual and paternity identification as well as population genetic analysis (QUELLER et al., 1993; WOODRUFF, 1993). To date, many PCRbased primers designed for one species are readily applicable to closely related species (MoORE et al., 1991). For nonhuman primates in particular, cross species amplification is greatly benefited by the human genome project that cloned far more microsatellites in human than in any other living creatures (e.g. in Altmann et al., 1996; CoOTe \& Bruford, 1996; KeANE et al., 1997; KAYSER et al., 1996; Morin \& SMith, 1995; Morin et al., 1997; NuRnberg et al., 1998).

In conventional genetic studies, animals have to be captured or sacrified. The trapping and handling procedures may be stressful to the subject animals, while killing is not preferred or allowed in some circumstances. Alternative approaches are encouraged to overcome such drawbacks especially in wildlife studies (WOODRUFF, 1993). Through PCR amplification, it is now possible to conduct genetic analysis from samples collected non-invasively, such as feces (CONSTABLE et al., 1995; GerlofF et al., 1995; KoHN \& WAYNE, 1997), chewed wadges (TAKASAKI \& TAKENAKA, 1991; TAKEnAKA et al., 1993), and shed hairs (MORIN et al., 1993, 1994).

In this paper, firstly, we screened microsatellite primers from other primates for their polymorphism in $M$. cyclopis, and, secondly, we reported the use of these loci in paternity identification of a captive monkey group. Furthermore, by adopting a low-invasive method for hair, blood, and ejaculate sample collection, we evaluated the possibility of using these samples in microsatellite typing.

\section{MATERIALS AND METHODS}

Blood samples of 12 unrelated $M$. cyclopis from Taipei Zoo and Eastern Wildlife Rescue Center were used to examine the polymorphism of microsatellite loci. Thirty-six microsatellite loci that have been reported to yield microsatellite products in other Macaca species (ALTMANN et al., 1996; CoOTe \& Bruford, 1996; Crouse \& SChumm, 1995; Domingo-Roura et al., 1997; InOue \& TAKENAKA, 1993; KAYSER et al., 1996; KEANE et al., 1997; Weber et al., 1990) were selected. DNA samples of a parent-offspring triad in Taipei Zoo were used to check the Mendelian inheritance in some loci. Paternity test was conducted on members of a captive group in Taipei Zoo. This monkey group consisted of nine individuals: one nulliparous female $(F I)$, two mother-offspring pairs $(F 2-J 2, F 3-J 3)$, one orphaned juvenile $(J 4)$, and three fully matured males $(M I, M 2$, and $M 3$, ordered by rank). The juveniles were born in 1995 and the adult males were putative fathers of the juveniles.

In order to access the validity of the samples collected in low-invasive ways, the allelic patterns of the DNA extracted from blood and from other sources of the same individuals were compared for consistency. Hair and blood samples of zoo animals were examined in four loci. Samples were also collected from a provisioned monkey population in Chai-shan, southern Taiwan. Monkeys of this population are well habituated to people and could tolerate slight contact. Intensive behavioral observation on one particular troop during the mating season of 1996- 1997 allowed us to collect samples of various sources from known individuals. Hairs and menstrual bleeding of an adult female, $A 08$, were collected. Hairs were plucked barehanded. Menstrual bleeding of $A 08$ was swabbed up by a cotton-tipped applicator stick. Blood and ejaculate samples were collected from an adult male, M09. Blood was obtained when M09 was wounded by another male. Ejaculate samples were collected after $M 09$ copulated with females.

Hair samples were preserved in dry, sealed envelopes. Blood and ejaculate samples were 
preserved in $2 \mathrm{ml}$ vials with $1 \mathrm{ml}$ STE buffer $(10 \mathrm{mM}$ Tris- $\mathrm{HCl}, 1 \mathrm{mM}$ EDTA, $0.1 \mathrm{M} \mathrm{NaCl}$, $\mathrm{pH}=8.0$ ), and pure ethanol was added to a total volume of $2 \mathrm{ml}$. All the samples were preserved in $-20^{\circ} \mathrm{C}$.

Nuclear DNA was extracted by standard phenol-chloroform procedure (KocHER et al., 1989). PCR reaction mixture contained 10 pmole of both forward and reverse primer sets, $50-400 \mathrm{uM}$ dNTP, 2-4 mM MgCl 2,1 X PCR reaction buffer (20 mM Tris- $\mathrm{HCl}, \mathrm{pH} 8.4,20 \mathrm{mM} \mathrm{KCl}$ ), 1 unit taq polymerase (Platinum ${ }^{\mathrm{TM}}$ Taq DNA Polymerase, GIBCO BRL) and 20-200 ng DNA in a total volume of 25 ul. DNA thermal cycler (Biometra) was programmed to perform an initial denaturation at $95^{\circ} \mathrm{C}$ for $5 \mathrm{~min}, 35$ cycles of $20 \mathrm{~s}$ at $95^{\circ} \mathrm{C}, 20 \mathrm{~s}$ at annealing temperature (see Table 1), and $20 \mathrm{~s}$ at $72^{\circ} \mathrm{C}$. A 5 -min final extension at $72^{\circ} \mathrm{C}$ was also included. PCR products $(1-3 \mathrm{ul})$ were separated on $8 \%$ non-denaturing polyacrylamide gels of dimensions $16 \times 20 \times 0.075 \mathrm{~cm}$ in Model V-16-2 vertical gel electrophoresis system (GIBCO BRL). Electrophoresis was conducted at $230 \mathrm{~V}$ for 2 hours. Marker standards, pBR322 digested with MspI (Biolab) and $\varphi 174$ digested with HinfI (MBI), were loaded on each gel to provide standards for sizing microsatellite alleles. The microsatellite fragments were visualized by silver staining modified after TEGELSTROM (1986).

\section{RESULTS}

Among the 36 loci, 11 [D5S85, D5S87, D5S88, D12S66, D14S281, D14S52, F8vWF, MFGT2, MFGT17, MFGT19, and TOP(X)] failed to yield specific PCR products; 4 showed monomorphic band (D3S1238, 126 bp; D5S807, 200 bp; D5S818, 149 bp; and D13S159, $160 \mathrm{bp}$ ); and the other 21 loci were polymorphic (Table 1).

Based on the number of alleles observed in 12 monkeys, the 21 polymorphic loci can be

Table 1. PCR condition, gene diversity, and observed heterozygosity values for the 21 polymorphic microsatellite loci in Macaca cyclopis.

\begin{tabular}{llllll}
\hline Locus & $\begin{array}{l}\text { Repeat } \\
\text { motif }\end{array}$ & $\begin{array}{l}\text { Number of } \\
\text { alleles }\end{array}$ & $\begin{array}{l}\text { Fragment } \\
\text { range }(\mathrm{bp})\end{array}$ & $\begin{array}{l}\text { Annealing } \\
\text { temperature }\left({ }^{\circ} \mathrm{C}\right)\end{array}$ & Heterozygosity \\
\hline D1S188 & $\mathrm{di}$ & 6 & $146-176$ & 55 & 0.58 \\
D1S207* & $\mathrm{di}$ & 5 & $152-166$ & 55 & 1.00 \\
D5S1470 & tetra & 7 & $170-232$ & 57 & 0.50 \\
D5S820 & tetra & 10 & $177-255$ & 57 & 0.75 \\
D6S271 & di & 7 & $184-196$ & 50 & 0.50 \\
D6S287 & di & 2 & 107,123 & 50 & 0.50 \\
D6S311 & di & 5 & $234-252$ & 55 & 0.08 \\
D7S503 & di & 8 & $136-162$ & 55 & 0.67 \\
D11S925 & di & 3 & $218,236,240$ & 54 & 0.08 \\
D12S67 & tetra & 9 & $112-116,205$, & 50 & 0.83 \\
& & & $213,269-285$ & & 0.50 \\
D14S255 & di & 6 & $201-211$ & 56 & 0.58 \\
D16S265* & di & 6 & $80-92$ & 55 & 0.55 \\
D17S791 & di & 6 & $176-192$ & 55 & 0.83 \\
MFGT5 & di & 6 & $134-162$ & 55 & 0.83 \\
MFGT18 & di & 7 & $88-106$ & 57 & 0.33 \\
MFGT21 & di & 6 & $98-124$ & 50 & 0.83 \\
MFGT22 & di & 10 & $98-134$ & 50 & 0.12 \\
MFGT24 & di & 3 & $104,108,110$ & 50 & 0.67 \\
MFGT25 & di & 9 & $116-158$ & 44 & 0.92 \\
MFGT27 & di & 9 & $176-200$ & 54 & 0.08 \\
NF1 & di & 2 & 170,172 & 50 & \\
\hline
\end{tabular}

*Sample sizes for D1S207 and D16\$265 are 10 and 11, respectively. For the other loci, a total of 12 animals were typed. 
divided into three groups: 4 less polymorphic loci with only two or three alleles, 13 moderately polymorphic loci with five to eight alleles, and 5 highly polymorphic loci with more than eight alleles. Among the polymorphic loci, 3 are tetra-nucleotide and the other 18 are di-nucleotide repeat. The average of the observed heterozygosity of the 21 loci is 0.56 (Table 1).

Table 2 compares the allelic sizes of the five highly polymorphic loci between $M$. cyclopis and other primate species. All except D12S67 showed similar allelic size ranges among different species. In locus D12S67, the three closely related species, $M$. cyclopis, $M$. mulatta, and $M$. fascicularis, have two common groups of alleles (c.a. $120 \mathrm{bp}$ and $200 \mathrm{bp}$ ). Nevertheless, in $M$. cyclopis, there was one more group of longer alleles that were absent in the other two macaque species.

Genotypes of the parent-offspring triad were determined in eight loci, D5S820, D6S271, D6S311, D12S67, D14S255, MFGT21, MFGT22, and MFGT27. All the loci follow Medelian inheritance. Paternity of the juveniles $J 2-J 4$ was analyzed by the highly polymorphic loci. Discrimination was achieved in the second locus tested (Fig. 1). The result shows that all the three juveniles in the captive group were descendants of the top-ranking male $M 1$. Moreover, by the extremely polymorphic locus D12S67 alone, paternity of the orphaned $J 4$ could even be determined without knowing the genotype of its mother.

DNA from hair and blood samples of zoo animals gave concordant result in the four loci tested; major bands were the same for hair and blood DNA. However, DNA from hairs produced more artificial bands than those from blood (Fig. 2). Both the ejaculate and blood samples of a male monkey as well as the hair and menstrual bleeding samples of a female monkey are equally valid in microsatellite typing (Fig. 3). The result indicates that menstrual bleeding, blood, ejaculate, and hair samples can serve as DNA sources for genetic studies.

\section{DISCUSSION}

Microsatellites are not only conservative in closely related species (MoORE et al., 1991), some of them were proved to be homologous within primate order (PERELYGIN et al., 1996). These

Table 2. Comparison of the highly polymorphic loci between Macaca cyclopis and other species.

\begin{tabular}{|c|c|c|c|c|}
\hline Locus & Species & No. of alleles & No. of individuals typed & Fragment range (bp) \\
\hline D5S820 & $\begin{array}{l}\text { M. cyclopis } \\
\text { M. mulatta } \\
\text { Human }^{2)}\end{array}$ & $\begin{array}{r}10 \\
9 \\
8\end{array}$ & $\begin{array}{l}12 \\
\text { Not available } \\
\text { Not available }\end{array}$ & $\begin{array}{l}177-255 \\
181-213 \\
190-218\end{array}$ \\
\hline D12S67 & $\begin{array}{l}\text { M. cyclopis } \\
\text { M. mulatta } \\
\text { M. } \text { fascicularis }^{3)} \\
\text { Human }^{3)}\end{array}$ & $\begin{array}{r}9 \\
17 \\
3 \\
12\end{array}$ & $\begin{array}{r}12 \\
86 \\
2 \\
394\end{array}$ & $\begin{array}{l}112-116,205,213,269-285 \\
108-128,181-249 \\
124,193,205 \\
229-273\end{array}$ \\
\hline MFGT22 & $\begin{array}{l}\text { M. cyclopis } \\
M . \text { fuscata }^{4}\end{array}$ & $\begin{array}{r}10 \\
8\end{array}$ & $\begin{array}{l}12 \\
14\end{array}$ & $\begin{array}{l}98-134 \\
98-126\end{array}$ \\
\hline MFGT25 & $\begin{array}{l}\text { M. cyclopis } \\
\text { M. fuscata }\end{array}$ & $\begin{array}{l}9 \\
9\end{array}$ & $\begin{array}{l}12 \\
14\end{array}$ & $\begin{array}{l}116-158 \\
126-160\end{array}$ \\
\hline MFGT27 & $\begin{array}{l}\text { M. cyclopis } \\
\text { M. fuscata }\end{array}$ & $\begin{array}{l}9 \\
4\end{array}$ & $\begin{array}{l}12 \\
14\end{array}$ & $\begin{array}{l}176-200 \\
164-174\end{array}$ \\
\hline
\end{tabular}

Sources of information: I) NURnBERG et al., 1998; 2) The Cooperative Human Linkage Center, CHLC (http://www.chlc.org); 3) KAYSER et al., 1995; 4) DOMINGo-Roura et al., 1997. 
(a)

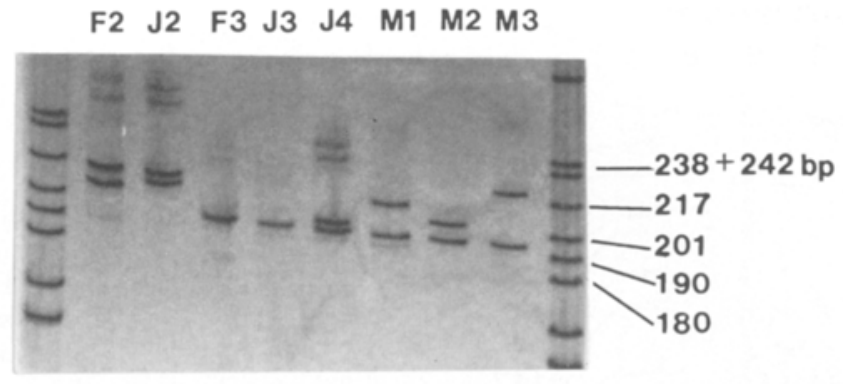

(b)

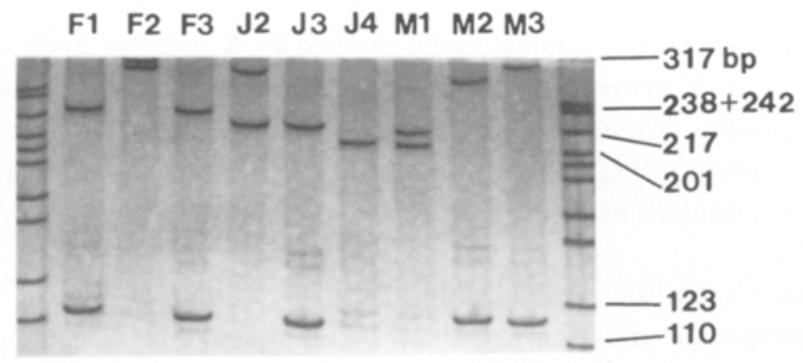

Fig. 1. Banding patterns of the loci D5S820 (a) and D12S64 (b) used for paternity identification of a captive monkey group in Taipei Zoo. Males $(M I-M 3)$ were putative fathers of the juveniles $(J 2-J 4) . J 2$ and $J 3$ were offspring of females $F 2$ and $F 3, F 1$ was a nulliparous female and $J 4$ was an orphan. In the right and left margins are size standards of marker pBR322 digested with MSPI restriction enzyme. In locus D5S820 (a), only $J 2$ could be determined as $M I$ 's offspring. In locus D12S67 (b), all juveniles $(J 2-J 4)$ could be identified as $M I$ 's offspring.
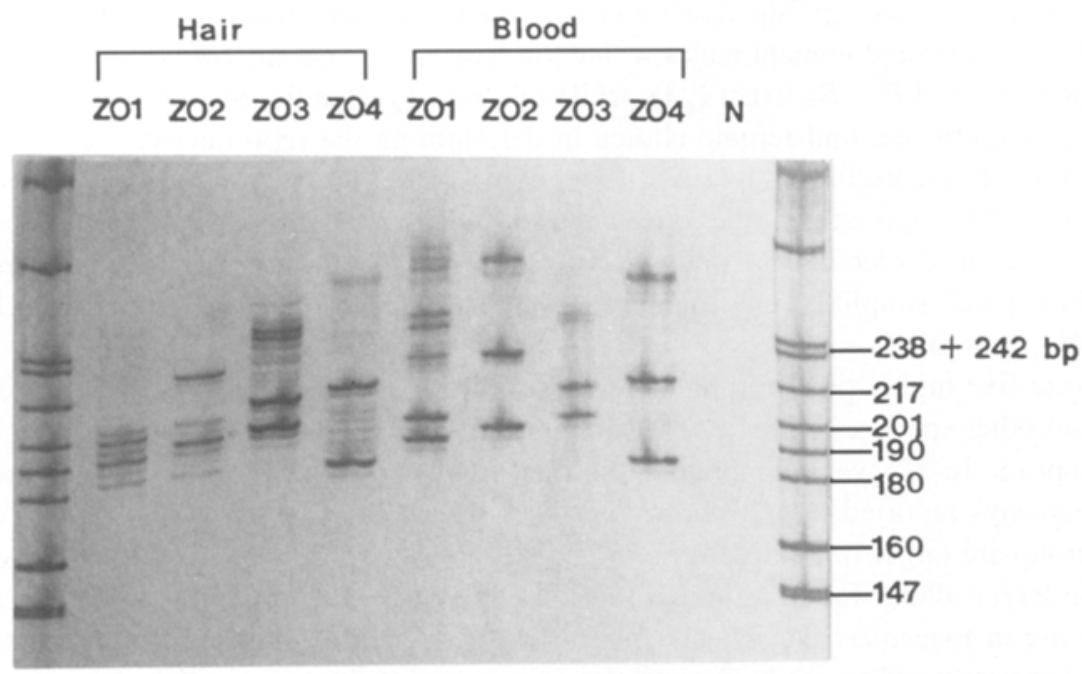

Fig. 2. Microsatellite alleles of D5S820 amplified from hair (left) and blood (right) DNA samples of monkeys (Z01-Z04) kept in Tajpei Zoo. N denotes negative control. The right and left margins are size standards of marker pBR322 digested with MSPI restriction enzyme. 
A08 A08 M09 M09

H B E B

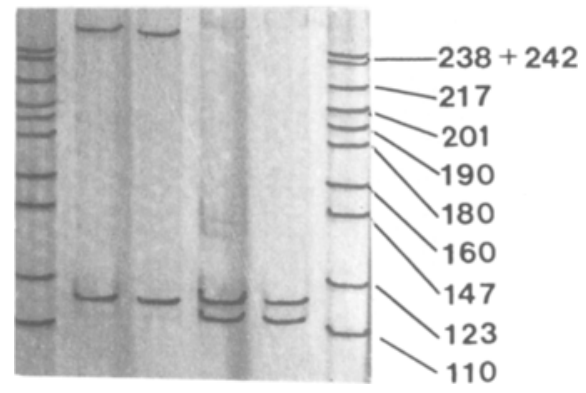

Fig. 3. Microsatellite alleles of D12S67 amplified from hair $(\mathrm{H})$ and blood $(\mathrm{B})$ samples of a female $(A 08)$ and from ejaculate (E) and blood (B) samples of a male (M09). Samples were collected from a provisioned monkey population in Chaishan, southern Taiwan. The right and left margins are size standards of marker pBR322 digested with MSPI restriction enzyme.

characteristics facilitate cross-species application of PCR primers in closely related species. In this study, microsatellite primers developed in human and $M$. fuscata were tested for validity and screened for polymorphism in M. cyclopis. Polymorphism was observed in 21 out of the 36 loci tested. These polymorphic loci, along with the procedures developed for low-invasive sampling from natural populations, will be useful tools for future studies on conservation genetics of M. cyclopis.

The low-invasive sampling method employed in our study is readily applicable to field primatologists. Collection of wound or menstrual bleeding and ejaculate samples is usually possible in habituated primate groups under intensive behavioral observation. Hairs can be plucked barehanded from good-tempered individuals that ignore slight contact and disturbance from researchers. However, it should be conducted with care to avoid biting or scratching by the animals.

Similar to other macaque species, $M$. cyclopis live in multimale social groups (KAWAMURA et al., 1988). During the mating season, females would mate with multiple males, including troop males and nontroop males (WU \& LiN, 1992). Males may employ different strategies to ensure their reproductive success which can only be accessed by molecular approaches. The relation between dominance and reproductive success of male primates has been studied extensively. Some studies found that dominant males would produce more offspring (DE RUITER \& VAN HOOFF, 1993; DiXSON et al., 1993; SMITH, 1993), while others suggested the role of sperm competition, male mating experience, and female choice in determining the reproductive success of males (BERARD et al., 1993; InOuE et al., 1993; PAul et al., 1993; Soltis et al., 1997). In the captive group examined in our study, the reproductive success is strongly related to dominance. However, it may be a special case in captivity rather than the general pattern for the species. In a confined area with simplified environment, lower-ranking males could hardly approach estrous females (Wu, pers. obs.).

Among the five highly polymorphic loci, four of them exhibit similar repeat array size in $M$. cyclopis and other species (Table 2). The banding pattern in the other locus, D12S67, deserves special attention. In M. cyclopis, three allelic size groups were found. Two of them are similar to the size groups reported in $M$. mulatta and $M$. fascicularis (KAYSER et al., 1995). Alleles of the third group are larger than those reported in the other two macaque species, and are comparable to the larger alleles found in human. KAYSER et al. (1995) proposed that the two common allelic groups in macaques consist of perfect (GATA)n shorter alleles and duplicated longer alleles, and the insertion event leading to the occurrence of the longer alleles was fixed in the common ancestor of the $M$. fascicularis species group. The two common allele groups observed 
in $M$. cyclopis provide evidence for the speculation by KAYSER et al. (1995). It is yet to be determined whether these alleles are present in the arctoides, sinica, and sylvanus-silenus species groups. Moreover, the existence of the largest allele group in $M$. cyclopis poses another interesting question. It might be resulted from other mutation events along the mulatta-cyclopis lineage. Further study in this particular locus may improve our knowledge on the evolutionary scenario of the Macaca genus.

Acknowledgements. We would like to thank Dr. J. H. CHI, Mr. J. F. LIN, and Taipei Zoo for providing valuable assistance and help. This work was in part supported by the National Science Council of the Republic of China. HYW was also supported by the research fund of the Institute of Zoology, Academia Sinica.

\section{REFERENCES}

Altmann, J.; Alberts, S. C.; Haines, S. A.; Dubach, J.; Muruthi, P.; Coote, T.; Geffen, E.; Cheesman, D. J.; Mututua, R. S.; SaiYalel, S. N.; Wayne, R. K.; LaCY, R. C.; BRuford, M. W. 1996. Behavior predicts genetic structure in a wild primate group. Proc. Natl. Acad. Sci. U. S. A., 93: 5797-5801.

Berard, J. D.; Nürnberg, P.; EpPlen, J. T.; SChmidTKe, J. 1993. Male rank, reproductive behavior, and reproductive success in free-ranging rhesus macaques. Primates, 34: 481-489.

Constable, J. J.; Packer, C.; Collins, D. A.; Pusey, A. E. 1995. Nuclear DNA from primate dung. Nature, 373: 393.

COOTE, T.; BRUford, M. W. 1996. Human microsatellites applicable for analysis of genetic variation in apes and Old World monkeys. J. Hered., 87: 406-410.

Crouse, C. A.; SCHumm, J. 1995. Investigation of species specificity using nine PCR-based human STR systems. J. Foren. Sci. 40: 952-956.

DE RUITER, J. R.; VAN HoOFF, J. A. R. A. M. 1993. Male-dominance rank and reproductive success in primate groups. Primates, 34: 513-523.

Dixson, A. F.; Bossi, T.; Wickings, E. J. 1993. Male dominance and genetically determined reproductive success in the mandrill (Mandrillus sphinx). Primates, 34: 525-532.

Domingo-Roura, X.; Lopez-GiRaldez, T.; Shinohara, M.; TAKEnaKa, O. 1997. Hypervariable microsatellite loci in the Japanese macaque (Macaca fuscata) conserved in related species. Amer. J. Primatol., 43: $357-360$.

Gerloff, U.; Schlotterer, C.; Rassmann, K.; Rambold, l.; Hohmann, G.; Fruth, B.; Tautz, D. 1995. Amplification of hypervariable simple sequence repeats (microsatellites) from excremental DNA of wild living bonobos (Pan paniscus). Mol. Ecol., 4: 515-518.

Inoue, M.; Mitsunaga, F.; Nozaki, M.; Ohsawa, H.; Takenaka, A.; Sugiyama, Y.; Shimizu, K.; TAKENAKA, O. 1993. Male dominance rank and reproductive success in an enclosed group of Japanese macaques: with special reference to post-conception mating. Primates, 34: 503-511.

InOUE, M.; TAKEnAKA, O. 1993. Japanese macaque microsatellite PCR primers for paternity testing. Primates, 34: 37-45.

Kawamura, S.; Azuma, N.; Norikoshi, K. 1988. Socio-ecological Study of Free-living Formosan Monkeys (Macaca cyclopis) in Taipingshan Natural Park. Phys. Anthropol. Sect., Life Sci. Inst., Sophia Univ., Tokyo.

Kayser, M.; Nurnberg, P.; Bercovitch, F.; Nagy, M.; Roewer, L. 1995. Increased microsatellite variability in Macaca mulatta compared to humans due to a large scale deletion/insertion event during primate evolution. Electroph., 16: 1607-1611.

Kayser, M.; RitTer, H.; Bercovitch, F.; Mrug, M.; Roewer, L.; NurnberG, P. 1996. Identification of highly polymorphic microsatellites in the rhesus macaque Macaca mulatta by cross-species amplification. Mol. Ecol., 5: 157-159.

Keane, B.; Dittus, W. P. J.; Melnick, D. J. 1997. Paternity assessment in wild groups of toque macaques Macaca sinica at Polonnaruwa, Sri Lanka using molecular markers. Mol. Ecol., 6: 267-282.

Kocher, T. D.; Thomas, W. K.; Meyer, A.; Edwards, S. V.; PaAbo, S.; Villablanca, F. X.; Wilson, A. C. 1989. Dynamic of mitochondrial DNA evolution in animals: amplification and sequencing with conserved primers. Proc. Natl. Acad. Sci. U. S. A., 86: 6196-6200. 
KoHn, M. H.; WaYNe, R. K. 1997. Facts from feces revisited. Trends Ecol. Evol., 12: 223-227.

Masul, K.; NARITA, Y.; TANAKa, S. 1986. Information on the distribution of Formosan monkeys (Macaca cyclopis). Primates, 27: 383-392.

Moore, S. S.; Sargeant, L. L.; King, T. J.; Mattick, J. S.; Georges, M.; Hetzel, D. J. S. 1991. The conservation of dinucleotide microsatellites among mammalian genomes allows the use of heterologous PCR primer pairs in closely related species. Genomics, 10: 654-660.

Morin, P. A.; Kanthaswamy, S.; SMith, D. G. 1997. Simple sequence repeat (SSR) polymorphisms for colony management and population genetics in rhesus macaques (Macaca mulatta). Amer. J. Primatol., 42: $199-213$.

Morin, P. A.; SMITH, D. G. 1995. Nonradioactive detection of hypervariable simple sequence repeats in short polyacrylamide gels. Biotechniques, 19: 223-227.

Morin, P. A.; Wallis, J.; Moore, J. J.; Chakraborty, R.; Woodruff, D. S. 1993. Non-invasive sampling and DNA amplification for paternity exclusion, community structure, and phylogeography in wild chimpanzees. Primates, 34: 347-356.

Morin, P. A.; Wallis, J.; Moore, J. J.; WoodrufF, D. S. 1994. Paternity exclusion in a community of wild chimpanzees using hypervariable simple sequence repeats. Mol. Ecol., 3: 469-478.

Nurnberg, P.; Sauermann, U.; Kayser, M.; Lanfer, C.; Manz, E.; Widdig, A.; Berard, J.; Bercovitch, F. B.; Kessler, M.; SCHMIDTKE, J.; KRAwCZAK, M. 1998. Paternity assessment in rhesus macaques (Macaca mulatta): multilocus DNA fingerprinting and PCR marker typing. Amer. J. Primatol., 44: 1-18.

Paul, A.; Kuester, J.; Timme, A.; ArnemanN, J. 1993. The association between rank, mating effort, and reproductive success in male Barbary macaques (Macaca sylvanus). Primates, 34: 491-502.

Perelygin, A. A.; Kammerer, C. M.; Stowell, N. C.; Rogers, J. 1996. Conservation of human chromosome 18 in baboons (Papio hamadryas): a linkage map of eight human microsatellites. Cytogenet. Cell Genet., 75: 207-209.

Queller, D. C.; Strassmann, J. E.; Hughes, C. R. 1993. Microsatellites and kinship. Trends Ecol. Evol., 8: $285-288$.

SMITH, D. G. 1993. A 15-year study of the association between dominance rank and reproductive success of male rhesus macaques. Primates, 34: 471-480.

Soltis, J.; Mitsunaga, F.; Shimizu, K; Nozaki, M.; Yanagihara, Y.; Domingo-Roura, X.; Takenaka, O. 1997. Sexual selection in Japanese macaques, II: Female mate choice and male-male competition. Anim. Behav., 54: 737-746.

TAKasaki, H.; TAKenaka, O. 1991. Paternity testing in chimpanzees with DNA amplification from hairs and buccal cells in wadges: a preliminary note. In: Primatology Today, Ehara, A.; Kimura, T.; TAKENAKA, O.; IWAMOTO, M. (eds.), Elsevier, Amsterdam, pp. 612-616.

Takenaka, O.; Takasaki, H.; Kawamoto, S.; Arakawa, M.; Takenaka, A. 1993. Polymorphic microsatellite DNA amplification customized for chimpanzee paternity testing. Primates, 34: 27-35.

Tegelstrom, H. 1986. Mitochondrial DNA in natural populations: an improved routine for the screening of genetic variation based on sensitive silver staining. Electrophoresis, 7: 226-229.

Weber, J. L.; Kwitek, A. E.; May, P. E.; Patterson, D.; Drabkin, H. 1990. Dinucleotide repeat polymorphisms at the D8S85, D8S87 and D8S88 loci. Nucleic Acid Res., 18: 4038.

WoODRUFF, D. S. 1993. Non-invasive genotyping of primates. Primates, 34: 333-346.

WU, H. Y.; LIN, Y. S. 1992. Life history variables of wild troops of Formosan macaques (Macaca cyclopis) in Kenting, Taiwan. Primates, 33: 85-97.

Authors' Names and Present Addresses: JuI-HuA CHU, Institute of Zoology, Academia Sinica, Taipei, Taiwan 115, R. O. C.; HAI-YIN Wu, Institute of Natural Resources Management, National Dong Hwa University, Hualien, Taiwan, R. O.C. email: hywu@mail.ndhu.edu.tw; YI-Ju YANG, Department of Life Science, Tsu Chi College of Medicine and Humanities, Hwalien, Taiwan 970, R. O. C.; Osamu TaKenaKa, Primate Research Institute, Kyoto University, Inuyama, Aichi 4848506, Japan; YAO-SUng Lin, Institute of Zoology, National Taiwan University, Taipei, Taiwan 106, R. O. C. 